\title{
PENGARUH TERAPI MADU TERHADAP LUKA DIABETIK PADA PASIEN DENGAN DIABETES MELLITUS TIPE 2 DI RW 011 KELURAHAN PEGIRIAN SURABAYA
}

\author{
Fauziyah Sundari*, Hendro Djoko**
}

\begin{abstract}
ABSTRAK
Pendahuluan: Salah satu alternatif perawatan luka diabetik adalah menggunakan terapi madu. Madu memiliki kandungan air dan kelembapan yang cukup sehingga tidak mendukung bakteri untuk bertumbuh dan berkembangbiak. Survey yang dilakukan di daerah kelurahan Pegirian Surabaya, masih ada pasien DM yang mengalami luka diabetik dan melakukan perawatan menggunakan air dan betadin, larutan $\mathrm{NaCl} 0,9 \%$ dan serbuk Nebacetin. Tujuan penelitian ini untuk mengetahui pengaruh pemberian terapi madu terhadap luka diabetik. Metode: Desain penelitian menggunakan pra eksperimental dengan pendekatan one-group pre-post test. Populasi penelitian adalah pasien yang menderita luka diabetik sejumlah 10 orang, sampel diambil dengan menggunakan teknik Non Probability Sampling dengan pendekatan Total Sampling. Pengumpulan data menggunakan lembar observasi. Hasil: Hasil penelitian menunjukkan derajat luka diabetik sebelum dilakukan terapi madu sebagian besar dalam kategori berat yaitu 9 responden $(90 \%)$. Derajat luka diabetik setelah pemberian terapi madu diperoleh sebanyak 4 responden $(40 \%)$ dalam kategori sedang. Uji statistik menggunakan Wilcoxon didapatkan tingkat signifikasi $0,023(\rho<0,05)$ yang berarti ada pengaruh pemberian terapi madu terhadap luka diabetik pada pasien DM tipe 2 . Diskusi: Dengan demikian, terapi madu sangat membantu dalam proses penyembuhan luka diabetik pasien, sehingga di harapkan terapi ini dapat di jadikan pengobatan alternatif untuk penyembuhan luka diabetik
\end{abstract}

Kata Kunci : Luka diabetik, Terapi madu

\begin{abstract}
Introduction: One of alternative diabetic wounds is using honey therapy. Honey has enough moisture and that moisture does not supported bacteria to grows and multiplies. The survey conducted in Pegirian, Surabaya, there are diabetic patients who suffer diabetic wounds and did maintenance used water and betadin, $0.9 \% \mathrm{NaCl}$ solution and Nebacetin powder. The purpose of this study is to determine the effect of honey therapy on diabetic wounds in RW 011, Pegirian Surabaya. Methods: This studied design used pre experimental with one-group pre-post test approach. The population of the study were 10 patients suffering diabetic wounds, the sample was taken using Non Probability Sampling technique with Total Sampling approach. Data collection used with observation sheets. Results: The results showed that the 9 respondents (90\%) degree of diabetic injuries before the honey therapy was mostly in the heavy category, and the degree of diabetic injury after honey therapy was obtained by 4 respondents (40\%) in the moderate category. The statistic test used Wilcoxon showed that 0,023 $(\rho<0,05)$ significance level, that means there was effect of honey therapy on diabetic wounds in diabetes type 2 patient. Discussions: Thus, the honey therapy is very helpful in patient's diabetic wounds healing process, so this therapy can be made alternative medicine for healing diabetic wounds.
\end{abstract}

Keywords: Diabetic wounds, Honey Therap 


\section{PENDAHULUAN}

Diabetes Mellitus (DM) sering dikenal sebagai penyakit "kencing manis" merupakan masalah kesehatan yang ditandai dengan kadar gula darah tinggi dalam darah yang disebabkan oleh gangguan pada sekresi insulin, gangguan kerja insulin atau keduanya. Menurut American Diabetes Association (ADA) 2010, mendefinisikan DM sebagai suatu kelompok penyakit metabolik dengan karakteristik hiperglikemia yang terjadi karena kelainan sekresi insulin. Pada keadaan normal kadar gula diatur sedemikian rupa oleh insulin yang diproduksi oleh sel beta pankreas. Jika terjadi gangguan pada organ pankreas maka tidak menutup kemungkinan dapat menyebabkan tubuh kekurangan insulin.

Pada kondisi hiperglikemi dapat melemahkan kapasitas sekresi insulin dan menambah berat resistensi insulin yang dapat mempengaruhi proses metabolik dalam tubuh (Suharmiati, 2003). Hiperglikemi bila berkepanjangan dan tidak dikontrol dengan baik menyebabkan komplikasi angiopati dan neuropati. Kedua hal ini yang menyebabkan gangguan sirkulasi darah yang akan menghambat suplai oksigen pada serabut saraf dan kerusakan endotel pembuluh darah, hal ini akan memicu tumbuhnya bakteri terutama bakteri anaerob sehingga pada akhirnya timbul luka kaki diabetik. Pada luka diabetik, kulit dan jaringan sekitar luka akan berwarna kehitaman dan menimbulkan bau dimana kondisi ini memerlukan perawatan agar tidak terjadi masalah yang lebih berat. Berdasarkan hasil studi empiris, telah banyak hasil alam yang dapat dijadikan sebagai pengobatan alternatif penyembuhan luka diabetik, salah satunya adalah penggunaaan madu. Madu memiliki kandungan gula yang sangat tinggi yang dapat membantu membentuk lapisan pelindung yang mencegah bakteri masuk sekaligus menghambat pertumbuhan bakteri. Selain itu, madu juga mengandung berbagai macam enzim salah satunya enzim katalase yang memberi efek pemulihan pada luka (Hamad \& Sa'id, 2007).

Berdasarkan studi pendahuluan yang dilakukan oleh peneliti di RW 011
Kelurahan Pegirian, Kecamatan Semampir Surabaya Jawa Timur, terdapat beberapa penderita DM yang mengalami masalah pada kakinya dan melakukan perawatan pada lukanya dengan menggunakan air dan betadin saja, beberapa yang menggunakan larutan $\mathrm{NaCl}$ 0,9\%, dan serbuk nebacetin. Menurut WHO (2007), Indonesia termasuk sepuluh negara dengan jumlah kasus DM terbanyak di dunia. Pada tahun 2000, Indonesia berada pada peringkat keempat dengan jumlah kasus sebesar 8,4 juta orang, dan diperkirakan pada tahun 2020 nanti akan menjadi 300 juta orang bahkan diprediksi jumlahnya akan meningkat pada tahun 2030 menjadi 366 juta orang. (Depkes RI, 2008). Saat ini, sebanyak 17 provinsi di Indonesia, mempunyai prevalensi $\mathrm{DM} \mathrm{di}$ atas prevalensi nasional $(1,1 \%)$, diantaranya Aceh, Sumatra Barat, Riau, Bangka Belitung, Kepulauan Riau, DKI Jakarta, Jawa Barat, Jawa Tengah, DI Yogyakarta, Jawa Timur, NTB, NTT, Kaltim, Sulawesi Utara, Sulawesi Tengah, Gorontalo, dan Papua Barat. Pasien DM di Jawa Timur sendiri sudah mencapai 2,9\% dari jumlah penduduk. Pada tahun 2009-2010, DM menduduki urutan ke-5 penyakit terbanyak di puskesmas se-Jawa Timur setelah influensa, diare, hipertensi, dan tifus yaitu sebesar 3,66\% pada tahun 2009 dan 3,61\% pada tahun 2010 (DinKes Jatim, 2010).

Seperti pernyataan sebelumnya diatas, masyarakat yang menderita DM di RW 011 kelurahan Pegirian, kecamatan Semampir, Surabaya belum mengetahui perawatan luka diabetik yang tepat, beberapa pasien menolak pergi berobat karena faktor ekonomi, dan ada yang melakukan perawatan kakinya menggunakan air dan betadin, ada pula yang merawatnya menggunakan cairan $\mathrm{NaCl} 0,9 \%$. Penelitian Faisol (2015), tentang Efektivitas Pemberian Madu Terhadap Luka Diabetik menunjukkan bahwa setelah dilakukan perawatan didapatkan adanya pertumbuhan jaringan granulasi yang baru, tidak ada reaksi inflamasi, dan kedalaman luka berkurang, warna jaringan kemerahan, serta jumlah eksudat berkurang.

DM terjadi karena beberapa faktor yaitu faktor genetik, obesitas, kurang gerak, faktor makanan, hingga dapat terjadi komplikasi terjadinya luka pada kaki. Pada 
penderita DM dapat pula terjadi gangguan berupa kerusakan sistem syaraf (neuropati) yang terbagi menjadi tiga kelompok (kerusakan sistem saraf perifer, kerusakan sistem saraf otonom, dan kerusakan sistem saraf motorik). Kerusakan sistem saraf perifer pada umumnya dapat menimbulkan gejala kesemutan, nyeri pada tangan dan kaki, serta berkurangnya sensitivitas atau mati rasa (intensitivity), dimana kondisi ini akan sangat berbahaya karena penderita tidak dapat merasakan apa-apa sekalipun kakinya terluka, yang pada akhirnya mengakibatkan penderita terlambat untuk menyadari bahwa kakinya sudah terluka. Hal tersebut semakin diperparah karena kaki yang terluka tersebut tidak dirawat dengan baik dan mendapat perhatian serius, sehingga luka sukar sembuh bahkan akan menjadi borok/ulkus. Selanjutnya ulkus berkembang menjadi kematian jaringan, dan menyebabkan gangren. Dampak selanjutnya yang dapat terjadi pada pasien DM adalah komplikasi akut dan komplikasi kronik. Komplikasi akut biasanya terjadi ketoasidosis diabetik (KAD), hipoglikemi, asidosis laktat, dan infeksi berat. Sedangkan pada komplikasi kronik yang terjadi yaitu Penyakit Jantung Koroner (PJK), stroke, retinopati, nefropati, neuropati, dan ulkus pada kaki (Price \& Wilson, 2005). Pasien DM, memerlukan pengobatan dan perawatan luka yang baik. Pengetahuan dan pemahaman keluarga juga mempengaruhi tindakan yang dilakukan terhadap luka diabetik.

Penanganan luka diabetik dapat dilakukan dengan terapi farmakologis maupun terapi non farmakologis. Terapi farmakologis meliputi pemberian suntikan insulin, obat hipoglikemik oral (OHO). Madu merupakan salahsatu terapi nonfarmakologis yang bisa diberikan dalam perawatan luka DM. Pemberian terapi madu dapat dilakukan dengan membersihkan terlebih dahulu luka dengan cairan $\mathrm{NaCl} 0,9 \%$, kemudian dilakukan debridement (bila terdapat jaringan nekrosis), selanjutnya dibersihkan kembali dengan cairan $\mathrm{NaCl} 0,9 \%$, dikeringkan dengan kasa kering, kemudian diberikan 23 tetes madu di atas luka, diratakan dan ditutup dengan kasa kering. Berbagai penelitian ilmiah membuktikan bahwa kandungan fisika dan kimiawi dalam madu, seperti kadar keasaman dan pengaruh osmotik, berperan besar membunuh kumankuman. Selain itu, madu juga mengandung antibiotika sebagai antibakteri dan antiseptik untuk menjaga luka, sekaligus embantu mengatasi infeksi pada luka bahkan anti inflamasinya dapat mengurangi nyeri serta meningkatkan sirkulasi yang memberi kontribusi pada proses penyembuhan. Madu juga merangsang tumbuhnya jaringan baru, sehingga mengurangi timbulnya parut atau bekas luka pada kulit. Pengetahuan dan kepatuhan pasien DM merupakan salah satu upaya untuk mencegah infeksi, maupun mencegah kerusakan kulit semakin parah. Perawatan luka diabetik dapat dilakukan secara berkala dengan membersihkan dua kali dalam sehari. Para tenaga kesehatan perlu memberikan edukasi pada pasien maupun keluarganya. Berdasarkan pemaparan diatas, peneliti tertarik untuk mengetahui lebih jauh efektivitas terapi madu pada pasien DM dengan luka diabetik di RW 11 kelurahan Pegirian, kecamatan Semampir, Surabaya.

\section{METODE}

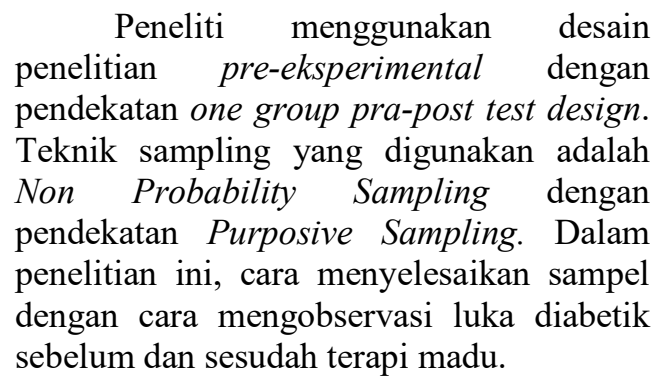

\section{HASIL}

Tabel 1. Karakteristik responden berdasarkan jenis kelamin di RW 011 Pegirian Surabaya, April 2016

\begin{tabular}{lcc}
\hline Jenis Kelamin & Frekwensi & $\%$ \\
\hline Laki-laki & 9 & 90 \\
Perempuan & 1 & 10 \\
\hline \multicolumn{1}{r}{ Total } & 10 & 13 \\
\hline
\end{tabular}

Berdasarkan tabel diatas dapat diketahui mayoritas responden berjenis kelamin lakilaki sebanyak 9 orang $(90 \%)$. 
Tabel 2. Karakteristik responden berdasarkan usia di RW 011 Pegirian Surabaya, April 2016

\begin{tabular}{|c|c|c|}
\hline Usia & Frekwensi & $\%$ \\
\hline $55-60$ thn & 5 & 50 \\
\hline $61-65$ & 3 & 30 \\
\hline $66-70$ & 2 & 20 \\
\hline$>70$ & 0 & 0 \\
\hline Total & 10 & 100 \\
\hline
\end{tabular}

Berdasarkan tabel diatas sebagian besar responden berusia 55-60 tahun yaitu sebanyak 5 orang $(50 \%)$.

Tabel 3. Karakteristik responden berdasarkan lama menderita luka di RW 011 Pegirian Surabaya, April 2016

\begin{tabular}{|c|c|c|}
\hline $\begin{array}{l}\text { Lama } \\
\text { menderita }\end{array}$ & Frekwensi & $\%$ \\
\hline $1-5$ thn & 7 & 70 \\
\hline $6-10$ thn & 3 & 30 \\
\hline$>10 \mathrm{thn}$ & 0 & 0 \\
\hline Total & 10 & 13 \\
\hline
\end{tabular}

Berdasarkan tabel diatas dapat diketahui mayoritas lama menderita luka responden antara 1-5 tahun sebanyak 7 orang (70\%).

Tabel 4. Hasil pengukuran derajat luka responden sebelum dilakukan terapi madu di RW 011 Pegirikan, Surabaya, 2016.

\begin{tabular}{cccc}
\hline No & $\begin{array}{c}\text { Derajat } \\
\text { Luka }\end{array}$ & Jumlah & Presentase \\
\hline 1 & Ringan & 1 & $10 \%$ \\
2 & Sedang & 0 & $0 \%$ \\
3 & Berat & 9 & $90 \%$ \\
\hline Jumlah & & 10 & $100 \%$
\end{tabular}

Berdasarkan tabel diatas, sebanyak 9 orang responden $(90 \%)$ katagori derajat luka termasuk derajat luka berat.
Tabel 5. Hasil pengukuran derajat luka sesudah dilakukan terapi madu dilakukan terapi madu di RW 011 Pegirikan, Surabaya, 2016.

\begin{tabular}{cccc}
\hline No & $\begin{array}{c}\text { Derajat } \\
\text { Luka }\end{array}$ & Jumlah & Presentase \\
\hline 1 & Ringan & 3 & $30 \%$ \\
2 & Sedang & 4 & $40 \%$ \\
3 & Berat & 3 & $30 \%$ \\
\hline & Total & 10 & $100 \%$
\end{tabular}

Berdasarkan tabel diatas, sebanyak 4 orang responden (40\%) katagori derajat luka termasuk derajat luka sedang.

Tabel 6. Tabulasi silang derajat luka sebelum dan sesudah dilakukan terapi madu di RW 011 Pegirikan, Surabaya, 2016.

\begin{tabular}{ccccc}
$\begin{array}{c}\text { Terapi } \\
\text { madu }\end{array}$ & Pre & $\%$ & $\begin{array}{c}\text { Pos } \\
\text { t }\end{array}$ & $\%$ \\
Derajat Luka & & & & \\
\hline Ringan & 1 & $10 \%$ & 3 & $30 \%$ \\
Sedang & 0 & $0 \%$ & 4 & $40 \%$ \\
Berat & 9 & $90 \%$ & 3 & $30 \%$ \\
\hline Total & 10 & 100 & 10 & 100 \\
& & $\%$ & & $\%$ \\
\hline
\end{tabular}

Hasil uji statistic wilcoxon : $\mathrm{p}=0,023<$ 0,05

Berdasarkan tabel diatas, terlihat adanya perubahan derajat luka sebelum dan sesudah diberikan terapi madu. Derajat luka katagori ringan bertambah jumlahnya dari 1 $(10 \%)$ menjadi 3 responden $(30 \%)$, derajat luka sedang juga berubah dari yang semula tidak ada menjadi 4 responden $(40 \%)$, dan untuk derajat luka berat terjadi penurunan dari 9 orang (90\%) menjadi 3 orang (30\%). Dan dari hasil uji statistik menggunakan Wilcoxon diperoleh $\rho=0,023$ yang berarti ada pengaruh terapi madu terhadap luka diabetikum. 


\section{PEMBAHASAN}

\section{Karakteristik Luka Diabetik Sebelum dilakukan terapi madu}

Berdasarkan tabel 4, distribusi hasil pengukuran derajat luka sebelum dilakukan terapi madu diperoleh 9 responden $(90 \%)$ mengalami derajat berat dan 1 responden (10\%) mengalami derajat ringan. Dari hasil tersebut dapat dikatakan bahwa sebagian besar responden di RW 011 Kelurahan Pegirian Surabaya mengalami luka diabetik dengan kategori derajat luka berat. Menurut Prabowo, (2007 dalam Situmorang, 2009), menyatakan bahwa luka diabetik adalah luka yang terjadi karena adanya kelainan pada saraf, pembuluh darah dan kemudian adanya infeksi. Beberapa faktor yang diduga berkaitan dengan berkembangnya masalah luka diabetik diantaranya adalah memiliki riwayat ulkus, gaya hidup yang tidak sehat, , infeksi, kadar gula darah yang tinggi. Faktor resiko yang terjadi tidak hanya satu, akan tetapi terdapat berbagai faktor karena faktor satu dengan faktor yang lain saling mendukung, seperti gaya hidup yang tidak sehat mendukung terjadinya peningkatan kadar gula darah yang tinggi sehingga beresiko terjadinya luka diabetik. Berdasarkan hasil observasi peneliti sebelum diberikan terapi madu banyak repsonden yang mengalami luka diabetik pada kategori berat, hal ini disebabkan karena kurangnya informasi tentang alternatif lain dalam membantu penyembuhan luka diabetik selain dengan cara medis yang dianjurkan oleh dokter, sehingga sampai saat ini responden hanya berfokus pada pengobatan medis saja. Dimana kita ketahui bahwa untuk penyembuhan luka diabetik membutuhkan jangka waktu yang cukup panjang dan membutuhkan biaya yang banyak pula. Hal inilah yang menyebabkan responden memiliki kecenderungan untuk merasa enggan melakukan perawatan secara medis dan jarang memanfaatkan fasilitas kesehatan yang ada. Saat peneliti mencoba menanyakan apa saja tindakan yang dilakukan responden untuk membantu menyembuhkan luka diabetik yang dialaminya, sebagian besar responden mengatakan bahwa mencoba berbagai alternatif lain berdasarkan informasi yang disampaikan dari orang-orang disekitar responden yang pernah mengalami hal tersebut, namun berdasarkan pernyataan responden tidak ada perubahan sama sekali pada luka yang dialami responden untuk itu responden jenuh dan enggan mencoba menggunakan alternatif yang lain. Sedangkan diketahui apabila luka diabetik tidak ditangani dengan baik akan menyebabkan komplikasi yang berat bahkan perlu melakukan tindakan serius misalnya amputasi sehingga untuk alternative pengobatan luka diabetik bukan hanya pengobatan medis saja tetapi ada alternatif lain yang sekiranya murah dan mudah dilakukan oleh responden di rumah. Hal inilah yang menyebabkan luka diabetik yang dialami responden termasuk katagori berat.

Berdasarkan tabel 1, diketahui mayoritas responden berjenis kelamin lakilaki yaitu sebanyak 9 orang $(90 \%)$. Menurut Morison, (2009), menyatakan bahwa lakilaki cenderung banyak mengalami masalah diabetes mellitus berhubungan dengan aktivitas yang sebanding dengan tekanan, dimana semakin tinggi aktivitas seseorang maka semakin tinggi pula tekanan yang diperoleh, sehingga laki-laki memiliki resiko lebih tinggi mengalami luka diabetik dibanding perempuan. Tekanan dan kekuatan/gesekan dapat mengganggu sirkulasi jaringan yang akan menyebabkan penyumbatan pada pembuluh darah dan mengakibatkan hipoksia serta memperbesar pembuangan metabolik yang dapat mengakibatkan nekrosis. Hal ini dapat dibuktikan saat peneliti menanyakan kepada responden, sebagian responden meyatakan bahwa saat bekerja atau melakukan aktivitasnya sehari-hari mereka jarang menggunakan alas kaki, sebab mereka menyampaikan kurang nyaman saat menggunakan alas kaki ataupun sepatu dan ketika kaki mengalami perlukaan mereka tidak langsung mengobatinya.

Berdasarkan tabel 2, dapat diketahui sebanyak 5 orang (42\%) responden berusia 55-60 tahun. Menurut Riyadi dan Sukarmin (2010), menyatakan bahwa seiring bertambahnya usia seseorang akan mengalami penurunan fisiologis yang cepat. Selain itu juga terjadi penurunan sensasi rasa pada kaki dan bagian tubuh lainnya, sehingga penurunan ini akan 
beresiko pada penurunan fungsi pankreas untuk memproduksi insulin. Berdasarkan data hasil penelitian yang dikaitkan dengan teori dimana banyak responden yang berusia 55-60 tahun, sehingga dengan bertambahnya usia responden maka resiko terjadinya luka akan semakin bertambah besar seiring dengan usia responden saat ini. Hal ini juga dapat dilihat dari kemampuan bergerak responden yang sudah mulai menurun dan melemahnya fisik, sehingga hal tersebut yang dapat memperburuk dan memperlambat penyembuhan luka.

Berdasarkan tabel 3, dapat dilihat bahwa luka yang diderita responden terbanyak adalah 1-5 tahun sejumlah 7 orang. Suyono (2004), mengatakan bahwa penderita diabetes mellitus yang telah lama menderita luka diabetik antara 1-5 tahun atau lebih, apabila kadar glukosa darahnya tidak dikendalikan dengan baik akan muncul komplikasi yang berhubungan dengan vaskuler sehingga responden dapat mengalami makroangiopati dan mikroangiopati yang akan mengakibatkan menurunnya sirkulasi darah akibat tersumbatnya pembuluh darah perifer yang akan menghambat suplai oksigen pada serabut saraf dan kerusakan endotel pembuluh darah, hal tersebut dapat memicu tumbuhnya bakteri dengan subur terutama bakteri anaerob, sehingga penyebab timbulnya luka diabetik pada kaki. Berdasarkan teori dan hasil penelitian, responden yang mengalami luka diabetik bervariasi mulai derajat 1 (ringan), derajat 2 (sedang), dan derajat 3 (berat). Hal tersebut juga dapat dikaitkan dengan faktor usia responden dan faktor-faktor lain yang belum diidentifikasi.

\section{Karakteristik Luka Diabetik Setelah Dilakukan Terapi Madu}

Berdasarkan tabel 5, distribusi derajat luka responden setelah dilakukan terapi madu, terlihat bahwa dari 10 responden terdapat 4 orang $(40 \%)$ mengalami derajat sedang, sebanyak 3 orang $(30 \%)$ mengalami derajat ringan dan berat. Dari hasil tersebut dapat dikatakan bahwa sebagian besar responden di RW 011 Kelurahan Pegirian Surabaya mengalami perubahan derajat luka setelah dilakukan terapi madu. Menurut Molan (1992 dalam Jeffrey dan Echazaretta, 1997) dan Basal et al (2009) menyatakan bahwa madu memiliki kandungan air 18,25\%: kelembaban/aktivitas air (AW) sebesar 0,58\%: Hidrogen peroksida sebesar 0,038 mmol/L: Keasaman (pH) sebesar 3,95: kandungan protein sebesar 0,29\%: Fruktosa sebesar 38,87\%: glukosa sebesar 29,98\% dan mineral sebesar $0,20 \%$. Rata-rata kandungan air pada madu sekitar 17\% dengan AW sebesar 0,56-0,62 hal ini tidak mendukung pertumbuhan kebanyakan bakteri yang membutuhkan AW sebesar 0,94-0,99 pertumbuhan bakteri dihambat oleh hydrogen peroksida, selain itu bakteri pathogen hanya bisa hidup pada $\mathrm{pH}$ antara 4,0-4,5.Madu juga merangsang tumbuhnya jaringan baru sehingga selain mempercepat penyembuhan juga mengurangi timbulnya parut atau bekas luka pada kulit.. Perawatan luka diabetik dengan menggunakan madu bertujuan untuk membunuh kuman (antibakteri), mengurangi inflamasi (antiinflamasi), serta menstimulasi dan mempercepat penyembuhan luka, dilihat dari perbedaan hasil penilaian status luka pada seluruh parameter penilaian. Berdasarkan hasil penelitian dan dikaitkan dengan teori, maka didapatkan bahwa Hal ini sesuai dengan pernyataan yang disampaikan oleh responden yang menyatakan bahwa lukanya agak mengering dan sudah lumayan membaik dari sebelumnya setelah dilakukan perawatan menggunakan madu selama 2 minggu jaringan nekrotik berkurang secara signifikan. selain itu saat dilakukan observasi pada luka diabetik setelah dilakukan terapi luka sudah tampak mengering, sudah tampak jaringan baru pada luka dan luka sudah tertutup oleh lapisan benang-benang fibrin berwarna putih halus, dan pus yang dihasilkan oleh luka sebelumnya sudah tampak berkurang bahkan menghilang, hal ini disebabkan oleh responden telah dilakukan tindakan pemberian terapi madu yang mana banyak responden yang mengalami perubahan pada luka diabetik menjadi kategori baik. Hal ini juga dikarenakan responden mengikuti prosedur yang diterapkan yaitu Perlakuan tersebut dilakukan selama 2 minggu dengan aturan pakai madu dioleskan pada luka setiap hari kurang lebih sehari dua kali, kemudian tutup luka dengan kasa kering, anjurkan pada responden untuk luka agar 
tetap dalam kondisi kering. Disisi lain dukungan dan kepercayaan dari keluarga terhadap penyembuhan bagi lansianya juga sangat besar dimana keluarga kooperatif terhadap tindakan yang dilakukan peneliti.

\section{Pengaruh Terapi Madu terhadap Luka Diabetik}

Berdasarkan tabel 6, distribusi data pengukuran derajat luka setelah dilakukan terapi madu terlihat bahwa dari 10 responden terdapat 3 orang $(30 \%)$ mengalami derajat ringan, sebanyak 4 orang $(40 \%)$ mengalami derajat sedang dan 3 orang $(30 \%)$ mengalami derajat berat. Dari hasil tersebut dapat dikatakan bahwa sebagian besar responden di RW 011 Kelurahan Pegirian Surabaya mengalami perubahan derajat luka setelah dilakukan terapi madu. Berdasarkan hasil uji statistik Wilcoxon menunjukkan $\mathrm{p}=0,023$ yang berarti $p<0,05$ dan demikian dapat diartikan bahwa HO ditolak yang menunjukkan bahwa terdapat pengaruh madu terhadap penyembuhan luka diabetik. Menurut Hastuti (2008), madu merupakan salah satu obat untuk proses penyembuhan luka yang tertua yang pernah ada, yang berfokus untuk mengatasi atau mempercepat penyembuhan luka. Kategori luka pada responden dari berat dapat berubah menjadi kategori sedang atau ringan Hal ini juga tidak terlepas dari kemauan dan kepatuhan responden untuk menyembuhkan luka diabetikum yang dialaminya dimana mereka setiap harinya selalu rajin untuk mengoleskan madu pada daerah luka setiap harinya dan tidak lupa diimbangi dengan pengaturan pola makan yang baik dan menjaga kebersihan pada daerah luka. Selain itu dukungan dari keluarga dapat membantu dalam proses penyembuhan pasien sebab adanya dukungan dapat meningkatkan kepercayaan pasien dan menjadi penyemangat pasien untuk sembuh.

\section{SIMPULAN}

Derajat luka diabetik responden sebelum pemberian terapi madu, di RW 011, Kelurahan Pegirian, Surabaya adalah derajat luka kategori berat. Sedangkan derajat luka diabetik responden sesudah pemberian terapi madu, di RW 011,
Kelurahan Pegirian, Surabaya adalah derajat luka kategori sedang. Dari hasil tersebut didapatkan ada pengaruh pemberian terapi madu terhadap derajat luka di RW 011, Kelurahan Pegirian, Surabaya

\section{SARAN}

Hasil penelitian dapat di gunakan sebagai metode pengobatan alternatif non farmakalogis yang dapat membantu proses penyembuhan luka diabetic.

Mahasiswa mengenal serta memahami tentang pengaruh terapi madu dan di harapkan mahasiswa dapat mengaplikasikanya pada saat praktek di lapangan atau di masyaraka

\section{DAFTAR PUSTAKA}

Adhi, Bayu, TI, Rodiyatul F. S. dan Hermansyah, 2011. An Early Detection Method of Type-22 Diabetes Mellitus in Public Hospital. Vol.9, No.2, Telkomnika

Al Fady Moh. Faisol, 2015. Madu dan Luka Diabetik. Yogyakarta. KDT

Badero \& Siswandi, 2009. Ilmu penyakit dalam. Jakarta : Salemba mdika. Corwin, 2001. Diabetes Mellitus, Penatalaksanaan Diabetes Mellitus Terpadu, FKUI. Jakarta

Darmono, 2007, Diabetes Mellitus Ditinjau dari Berbagai Aspek Penyakit Dalam. Diterjemahkan oleh : CV. Agung, Semarang

Grestein, Ben. Diana Wood, 2010. At a Glance Sistem Endokrin edisi 2 Jakarta:Penerbit Erlangga

Haviva, A.B. 2011. Dahsyatnya Mukjizat Madu untuk Kesehatan, Kecantikan, dan Kecerdasan. Jogjakarta: DIVA Press.

Hidayat, A.A. 2006. Pengantar Kebutuhan Dasar Manusia: Aplikasi Konsep dan Proses Keperawatan. Jakarta: Salemba Medika

Hastuti, R.T. 2008. "Faktor-Faktor Resiko Ulkus Diabetika Pada Penderita Diabtes Mellitus; Studi Kasus di RSUD Dr. Moewardi Surakarta". Tidak Diterbitkan. Tesis. 
Semarang:PS. Magister Epidemiologi Pasca Sarjana Universitas Diponegoro.

Mansjoer, A., et al. 2000. Kapita Selekta Kedokteran. Jilid I. Edisi 3. Jakarta : Media Aesculapius

Nursalam. 2003, konsep dan penerapan Metodologi Penelitian Ilmu Keperawatan. Jakarta : Salemba

Situmorang, L.L. 2009. "Efektivitas Madu Terhadap Penyembuhan Luka Gangren Diabetes Mellitus di RSUP H.Adam Malik Medan”. Tidak Diterbitkan. Skripsi. Sumatera Utara: PSIK FK Universitas Sumatera Utara.

Smeltzer, S.C., dan Bare, B.G. 2002. Buku Ajar Keperawatan Medikal Bedah Brunner \& Suddarth. Vol. 1. Edisi 8. Alih Bahasa oleh Agung Waluyo et al. Jakarta: EGC

Smeltzer, S.C., dan Bare, B.G. 2002. Buku Ajar Keperawatan Medikal Bedah Brunner@Suddarth. Vol. 2. Edisi 8. Alih Bahasa oleh Agung Waluyo et al. Jakarta: EGC

Sudoyo, A.W., et al. 2006. Buku Ajar Ilmu Penyakit Dalam. Jilid III. Edisi 4. Jakarta: FK Universitas Indonesia

Suyono S, 2005, Patofisiologi Diabetes Mellitus Dalam Soegondo $S \mathrm{dkk}$. Penatalaksanaan Diabetes Mellitus Terpadu, FKUI. Jakarta

Wardani, Anggita Kusuma. 2011. Pengetahuan Praktis Ragam Penyakit Mematikan Yang Paling Sering Menyerang Kita. BukuBiru 